\title{
Susceptibility of spotted wolffish Anarhichas minor to experimental infection with nodavirus and infectious pancreatic necrosis virus
}

\author{
Ann-Inger Sommer*, Mette Amundsen Strand, Elisabeth Rasmussen, \\ Saskia Mennen
}

Norwegian Institute of Fisheries and Aquaculture Research, 9291 Tromsø, Norway

\begin{abstract}
The spotted wolffish Anarhichas minor is a promising new species for cold-water aquaculture. The broad host-range of piscine nodavirus (NV) and infectious pancreatic necrosis virus (IPNV) makes them potentially pathogenic to new fish species in aquaculture. IPNV and NV strains highly pathogenic in farmed Atlantic salmon Salmo salar and halibut Hippoglossus hippoglassus, respectively, in Norway were used for the challenge of spotted wolffish. In general, water-borne infection with IPNV and NV resulted in significant mortality among juveniles $<1 \mathrm{~g}$. Cumulative mortality after bath-challenge and cohabitation was 60 to $75 \%$ in the smallest juveniles $(0.3 \mathrm{~g})$. Intramuscular and intraperitoneal injection of NV was $100 \%$ lethal to wolffish of $10 \mathrm{~g}$, and the groups at $12^{\circ} \mathrm{C}$ died before those at $7^{\circ} \mathrm{C}$. No cohabitants of this size died, but NV was still detectable in these individuals after $10 \mathrm{wk}$. A persistent IPNV infection with low mortality developed in bath-challenged juveniles of $0.7 \mathrm{~g}$, in which IPNV was still detectable 4 mo later. This study comprises a demonstration of experimental viral infections in cultured spotted wolffish, although to date no natural outbreaks of viral diseases have been reported in this species.
\end{abstract}

KEY WORDS: Viral nervous necrosis · VNN • Viral encephalopathy and retinopathy · VER · Nodavirus · Infectious pancreatic necrosis $\cdot$ IPN $\cdot$ IPN virus $\cdot$ Spotted wolffish

\section{INTRODUCTION}

Commercial production of spotted wolffish Anarhichas minor is a relatively new activity in marine fishfarming. This species is one of the most promising new candidates for cold-water aquaculture (Brown et al. 1995, Falk-Petersen et al. 1999). The spotted wolffish is common to the Barents Sea and other northern areas of the Atlantic, including the coastal waters of northern Norway. The optimal temperature for hatching and growth is 4 to $10^{\circ} \mathrm{C}$, which makes wolffish especially suited for cultivation in the northern part of Norway (Falk-Petersen et al. 1999). The spotted wolffish has several parasites in nature (Bristow \& Hjartarson 1996), and in aquaculture Trichodina spp. infections on fry have been a problem (Falk-Petersen et al. 1999). To date, mortality caused by atypical Aeromonas salmonicida has been the only bacterial problem reported in wolffish (Hellberg et al. 1996). No viral infections have been reported in wolffish yet, but are likely to appear in farmed species when production is intensified.

Several marine fish species are susceptible to aquatic birnaviruses, causative agents of infectious pancreatic necrosis (IPN). Natural and experimental infections with IPN virus (IPNV) have caused mortality in larvae and juveniles of Atlantic halibut Hippoglossus hippoglossus (Biering et al. 1994, Wood et al 1996). IPN is also a major problem in fry of salmonids, as well as in post-smolt Atlantic salmon Salmo salar (Wolf 1988, Krogsrud et al. 1989, Smail et al. 1992, Taksdal et al. 1997). In Norway, symptom-free IPNV carriers have been commonly reported among farmed Atlantic salmon (Melby et al. 1991).

Piscine nodavirus (NV) is responsible for viral nervous necrosis (VNN), or viral encephalopathy and retinopathy (VER), in more than 20 different marine fish species in Europe, Asia and Japan (Munday \& 
Nakai 1997), and recently in the USA (Curtis et al. 2001) and Atlantic Canada (Johnson et al. 2002). Like IPN, VNN has caused high mortality in fry of Atlantic halibut (Grotmol et al. 1995), and in Atlantic cod (Starkey et al 2001, Johnson et al. 2002). Recently a persistent infection of NV was reported in halibut juveniles (Johansen et al 2002).

The broad host-range of NV and IPNV makes these viruses potentially pathogenic to new fish species in aquaculture. The aim of the present study was to investigate the susceptibility of spotted wolffish juveniles to NV and IPNV strains highly pathogenic to farmed Atlantic salmon and halibut in Norway, and proactively study the possibility of VNN or IPN outbreak in this species. Some factors known to affect the outcome of these viral infections in fishes, such as host size, water temperature and infection route, were examined in 3 separate challenge experiments. However, the virulence of NV and IPNV was not compared.

\section{MATERIALS AND METHODS}

Initially, production of farmed spotted wolffish was small and limited the number of fish available for experimental studies. The present study was performed over a $4 \mathrm{yr}$ period, using 3 different generations of spotted wolffish progeny (P) produced in 1998, 2000 and 2001. Attempts at viral detection were done on all batches of non-challenged wolffish: in 2 pools of 5 juveniles sampled at the start and the end of the trials, as well as in dead individuals. Due to the low number of control fish in Expt 1, these were only tested at the end of the experiment. The 3 challenge experiments had different experimental designs (described below), but the following was recorded in all 3 experiments: mortality, clinical signs or changes in behaviour. In addition, all dead fish were collected daily. If there was no mortality, 5 fish were sampled 3 and $5 \mathrm{wk}$ after challenge, and all surviving fish from each challenged group were collected at the end of the experiment. All sampled fish were frozen at $-70^{\circ} \mathrm{C}$ for later viral detection.

Fish and rearing conditions. The fish were produced locally by Troms Steinbit A/S in Senja or at the Aquaculture Research Station at Kaarvika, using egg and sperm from broodstock of wild spotted wolffish held in captivity (Falk-Petersen et al. 1999). The larvae were offered live feed (Artemia sp.) mixed with dry feed (Skretting Marin nutra granules) for about $4 \mathrm{wk}$, followed by dry feed only. The juveniles were kept in seawater under $24 \mathrm{~h}$ continuous daylight at about $6^{\circ} \mathrm{C}$ before acclimation to the desired experimental temperature. No feed was given $24 \mathrm{~h}$ prior to challenge. During the challenge experiments, the fish were kept in shallow raceways $(20 \times 20 \times 100 \mathrm{~cm})$ that were divided into 2 or 3 separate chambers by use of a finemeshed net. Seawater was introduced at one end and flowed through the different chambers of the raceway at 2 to $31 \mathrm{~min}^{-1}$. All challenge experiments were performed at the Fish Health Laboratory at the Aquaculture Research Station by certified personnel and with approval of the Animal Research Council. Prior to injection, the fish were anaesthetised with benzocaine (50 $\mathrm{mg} \mathrm{l}^{-1}$ water), and those used for tissue samples were killed by an overdose of benzocaine.

Virus strains and preparation. Nodavirus (NV): Strain H-NV/RI97 was used for the challenge in Expts 1 and 2. Diseased, small juveniles of Atlantic halibut were collected during an outbreak of VNN in a commercial hatchery in the southern part of Norway, and kept frozen at $-70^{\circ} \mathrm{C}$. Whole fish were pooled, slightly thawed and homogenised in sterile phosphatebuffered saline (PBS) (10\% w/v solution) using a homogeniser (Polytron, Kinematica). After centrifugation at $2000 \times g$ for $10 \mathrm{~min}$ at $4^{\circ} \mathrm{C}$, the supernatant was filtered through a $0.8 \mu \mathrm{m}$ and then a $0.22 \mu \mathrm{m}$ sterile filter (Millipore) before use. NV was detected in the tissue homogenate by RT-PCR, but the NV titre was not determined until the striped snakehead (SSN-1) cell line (Frerichs \& Rodger 1996) became available (European Collection of Cell Cultures, ECACC). Subsequent titration of the tissue homogenate kept frozen at $-70^{\circ} \mathrm{C}$ suggested that an NV titre of $10^{5}$ to $10^{6} \mathrm{TCID}_{50}(50 \%$ tissue culture infective dose) $\mathrm{ml}^{-1}$ was used in Expts 1 and 2 .

Infectious pancreatic necrosis virus (IPNV): Strain H-IPNV/GW98, isolated during an epidemic among farmed Atlantic halibut juveniles in the northern part of Norway, was used in all 3 experiments. Another strain (S-IPNV/SH96) was isolated from Atlantic salmon post-smolt during an IPN outbreak in the western part of Norway, and was used for the challenge in Expt 1 only. Both strains were characterised as Serotype Sp. The Chinook salmon embryo, CHSE-214 cell line (ECACC) (Lannan et al. 1984) was used for IPNV isolation and propagation as previously described by Johansen \& Sommer (2001). Material from a second passage in the cell culture of the strains was used for all IPNV challenges.

Expt 1. A total of 152 healthy juveniles of spotted wolffish P1998 (average weight $10 \mathrm{~g}$, range 6.2 to $14.2 \mathrm{~g})$ were randomly divided into 2 groups. One group, consisting of 112 fish, was gradually acclimated to $12^{\circ} \mathrm{C}$, and the other group of 40 fish to $7^{\circ} \mathrm{C}$. We used 5 raceways; 3 of these were divided into 3 compartments, and the other 2 into 2 compartments by a finemeshed net. The experimental period was $72 \mathrm{~d}$.

Nodavirus trials: The impact of temperature and administration routes on susceptibility to NV was examined in juveniles submitted to intramuscular (i.m.) and intraperitoneal (i.p.) injection at $7^{\circ} \mathrm{C}$ and 
$12^{\circ} \mathrm{C}$. A possible water-borne infection by cohabitation was also studied by placing a non-treated fish group downstream of the virus-challenged groups in the same raceway. The persistence of NV infections over 10 wk was also examined in the cohabitation groups: 2 groups of 16 fish were i.m.-injected and 2 groups i.p.injected with $50 \mu \mathrm{l}$ of H-NV/RI97 in $10 \%$ (w/v) tissue homogenate prepared as described in second subsection (approximately $10^{4} \mathrm{TCID}_{50} \mathrm{fish}^{-1}$ ). Each group was placed into separate compartments of 2 raceways at 7 and $12{ }^{\circ} \mathrm{C}$, the i.m.-groups in the first chamber by the water inlet and the i.p.-groups in the second chamber of each raceway; 3 d later, 8 non-treated fish were placed in the third chamber of each raceway, by the water outlet. To serve as uninfected controls for Expt 1, 2 groups of 8 fish, i.m.- or i.p.-injected with $50 \mu \mathrm{l}$ of PBS, and 8 non-treated fish were placed in 3 separate chambers in a third raceway at $12^{\circ} \mathrm{C}$.

IPN-virus trials: Susceptibility to IPNV via bath infection was tested at $12^{\circ} \mathrm{C}$ only. Cohabitation and persistence were studied as described in the NV trials. We bath-challenged 2 groups of 16 fish for $3 \mathrm{~h}$ at $12^{\circ} \mathrm{C}$ in oxygenated seawater containing $10^{5} \mathrm{TCID}_{50} \mathrm{ml}^{-1}$ of the 2 isolates H-IPNV/GW98 and S-IPNV/SH96. Each group was placed in a 2-chamber raceway by the water inlet; 3 d later, 8 non-treated fish were placed in the second chamber of each raceway.

Expt 2. A total of 280 first-feeding spotted wolffish juveniles (P2000) were used in this experiment. One group consisting of 85 fish was gradually acclimated to $12^{\circ} \mathrm{C}$, and another group of 195 fish to $7^{\circ} \mathrm{C}$. During this 2 wk period, the group of juveniles kept at $12^{\circ} \mathrm{C}$ reached a mean weight of $1 \mathrm{~g}$ before challenge, while those kept at $7^{\circ} \mathrm{C}$ weighed only $0.3 \mathrm{~g}$ when they were simultaneously infected. We used 5 raceways, 2 were divided into 2 compartments by a fine-meshed net and 3 were undivided. The duration of these challenge experiments was $35 \mathrm{~d}$.

Nodavirus trials: The susceptibility of first-feeding juveniles to water-borne NV infection was studied by bath-challenge as well as the risk of virus transmission by cohabitation. The impact of increased fish size (from rearing at higher temperature) on development of VNN and mortality was also observed. We challenged 2 groups of 60 fish at 7 and $12^{\circ} \mathrm{C}$ (Expt 2a and 2b, respectively) by bath for $2 \mathrm{~h}$ in oxygenated seawater with $0.05 \%(\mathrm{w} / \mathrm{v})$ tissue homogenate prepared as described in second subsection. The water contained approximately $10^{3} \mathrm{TCID}_{50} \mathrm{ml}^{-1}$ of NV Strain HNV/RI97; $3 \mathrm{~d}$ after exposure 25 fish were placed downstream of the challenged group kept at $7^{\circ} \mathrm{C}$.

IPN-virus trial: The susceptibility of first-feeding juveniles to water-borne IPNV infection, by bath and cohabitation, was studied in the $0.3 \mathrm{~g}$ juveniles only. A group of 60 fish at $7^{\circ} \mathrm{C}$ (Expt 2c) were bath-challenged in $10^{5} \mathrm{TCID}_{50} \mathrm{ml}^{-1}$ of H-IPNV/GW98 and 25 fish were placed downstream, as described in Expt 2a. As uninfected controls for Expt 2, 2 groups of 25 fish were kept in separate raceways at 7 and $12^{\circ} \mathrm{C}$. The control fish were mock-infected in seawater containing cell medium without virus.

Expt 3. A total of 110 spotted wolffish juveniles (P2001) of $0.7 \mathrm{~g}$ kept at natural seawater temperature (about $10^{\circ} \mathrm{C}$ at that time of the year) were acclimated to $12^{\circ} \mathrm{C}$ over a few days.

IPN-virus trial: The susceptibility of small juveniles bath-challenged with IPNV at $12^{\circ} \mathrm{C}$ was investigated. The experiment lasted nearly $16 \mathrm{wk}$ in order to determine if a carrier state of IPNV was established. We bath-challenged 2 groups of 55 fish as described for Expt 2 with $10^{5}$ TCID $_{50} \mathrm{ml}^{-1}$ of H-IPNV/GW98 or mockinfected in seawater containing cell medium and kept them in separate raceways at $12^{\circ} \mathrm{C}$.

Detection of virus. Heads (with brain and eyes) were used for NV detection in larger juveniles from Expt 1, while for IPNV detection the intestines were used. In Expt 2, whole fish were used for both NV and IPNV detection in the smallest juveniles. In Expt 3, bodies (with abdominal organs) without head and caudal part were used for IPNV detection.

$\boldsymbol{R T}$-PCR for detection of nodavirus: Total RNA was extracted from whole tissue or liquid homogenate using TriPure or Trizol LS Reagent (Life Technologies), according to the protocols provided by the manufacturer. We used 2 RT-PCR protocols to verify the presence of NV in tissue homogenates from sampled fish. Initially, a method using primers based on striped jack nervous necrosis virus (SJNNV) RNA2 (Nishizawa et al. 1994) was used for NV detection in Expt 1. A target region, T4, on the SJNNV capsid protein gene was amplified using Primers F2 and R3, with a resulting PCR product of $426 \mathrm{bp}$. Using this primer set, a PCR product of $420 \mathrm{bp}$ was obtained from halibut NV, due to a lack of 6 nucleotides in T4 compared to SJNNV (Grotmol et al. 2000). Later, a method described by Grotmol et al. (2000) based on an Atlantic halibut NV (AH95NorA) RNA2 gene sequence was used in Expt 2. Testing of the cohabitants from Expt 1 was also repeated. Primer Set AH95-F1 and AH95-R1 generates a PCR fragment of $341 \mathrm{bp}$ (T7) from the halibut NV capsid protein gene.

Sequence analysis: The F2 and R3 primers were applied for amplification of the T4 region of the NV strain (H-NV/RI97) used for challenge, and of the NV detected in dead juveniles from 2 different raceways (Expt 1). The RT-PCR products were sequenceanalysed at Genome Express, Grenoble, France. Nucleotide sequence comparisons to published sequences were performed with the WU-BLAST 2 program (Altschul et al. 1997), and the FASTA program (Pearson 1990), both hosted by the EBI server (www2. 
ebi.ac.uk). The sequence obtained from H-NV/RI97 and submitted to the EMBL Nucleotide Sequence Database was assigned Accession No. AJ536693.

IPN virus detection in cell culture: IPN was verified by inoculating CHSE-214 cells with 0.5, 0.05 and $0.005 \%(\mathrm{w} / \mathrm{v})$ sterile-filtered, homogenised tissue samples prepared as described in second subsection. Development of a cytopathic effect (CPE) due to IPNV was read and identified by neutralisation using IPNVspecific polyclonal antibodies produced in rabbit. The TCID $_{50}$ was determined by end-point dilution and calculated according to Reed \& Muench (1938). CHSE214 cells in 96-well tissue-culture plates (Nunclon) were inoculated with virus sample diluted 10-fold in 8 parallel wells. For detection of virus at low levels, an IPNV carrier test including 3 blind passages was performed in cell-culture bottles $\left(25 \mathrm{~cm}^{2}\right)$ (Nunclon). The lower detection level for a carrier test was approximately 10 to 20 infectious particles $\mathrm{g}^{-1}$ tissue.

Statistical analysis. A chi ${ }^{2}$-test was used to analyse mortality in 2 groups of fish for significance of differences (Wardlaw 1995). Expected numbers were calculated in groups of less than 20 fish (Expt 1) to ensure that use of the $\mathrm{chi}^{2}$-formula was permissible.

\section{RESULTS}

All 3 batches of spotted wolffish were healthy, and no NV or IPNV could be detected in non-challenged dead individuals, or in carrier tests of pools of 5 juveniles that were sampled at the start and at the end of the trials. Mortality reached $19 \%$ in the nonchallenged juveniles weighing less than $1 \mathrm{~g}$, but was very low or absent when they exceeded $1 \mathrm{~g}$. In Expt 2, a combination of faster growth and higher mortality rate of the smallest and weakest individuals during the 2 wk of acclimation to $12^{\circ} \mathrm{C}$ resulted in an average weight of $1.0 \mathrm{~g}$ before challenge compared to $0.3 \mathrm{~g}$ for individuals acclimated to $7^{\circ} \mathrm{C}$. Except for the large juveniles in Expt 1, all weighing before challenge was done using 2 pools of 10 fish, and therefore no individual weight variances were available.

\section{Challenge with nodavirus}

Clinical signs and mortality. The $10 \mathrm{~g}$ juveniles (Expt 1) intramuscularly (i.m.) or intraperitoneally (i.p.) injected with nodavirus started to display clinical signs 1 wk post-challenge. After 2 wk, all injected fish showed the same symptoms: darker pigmentation, reduced appetite, lethargy and straightening of their typical curled-up tail. No clinical signs were observed among the cohabiting or control groups. Cumulative mortality reached $100 \%$ between 4 and 7 wk after infection in all 4 groups of i.m.- and i.p.-injected fish (Fig. 1). Comparison of the i.m. and i.p. groups between the 2 temperatures showed that the mortality started earlier and increased significantly faster at 12 than at $7^{\circ} \mathrm{C}$, especially after i.p. injection $(\mathrm{p}<0.001$, $\mathrm{chi}^{2}$-test). When all i.m.- and i.p.-injected fish kept at $12^{\circ} \mathrm{C}$ had died, 30 and $33 \mathrm{~d}$ after challenge respectively, only 30 and $20 \%$ mortality was recorded among the same groups at $7^{\circ} \mathrm{C}$. Mortality started earlier in the i.p.-injected groups, but the disease seemed to develop more acutely in the i.m.-challenged groups. This difference was significant between the i.m.- and i.p.groups kept at $7^{\circ} \mathrm{C}$, and only $40 \%$ mortality was registered in the i.p.-group when the total i.m.-group had died ( $p<0.05$, chi $^{2}$-test). No mortality was observed among the control or cohabiting groups.

It was difficult to observe any signs of disease in the very small (0.3 g) juveniles (Expt 2a), although mortality was high. The cumulative mortality in the bathchallenged group kept at $7^{\circ} \mathrm{C}$ reached $75 \%$ within approximately $2 \mathrm{wk}$ (Fig. 2). VNN was transmitted to healthy fish by cohabitation with infected juveniles, and acute mortality followed a few days later, reaching $65 \%$ in this group. Cumulative mortality in both infected groups was significantly higher than the background mortality of $19 \%$ in the mock-infected juveniles ( $p<0.001, \mathrm{chi}^{2}$-test). In Expt $2 \mathrm{~b}$, the somewhat larger juveniles (or older by degree-days) showed a cumulative mortality of only $26 \%$ after NV challenge at $12{ }^{\circ} \mathrm{C}$ (Fig. 3). This was not significantly higher than the mortality of $16 \%$ observed in the

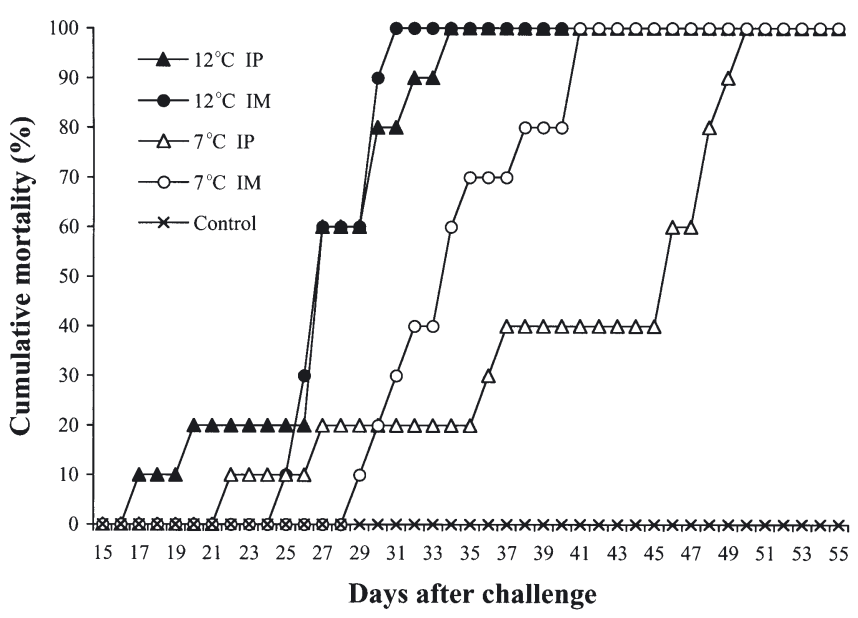

Fig. 1. Anarhichas minor. Cumulative mortality of wolffish (10 g) challenged at 7 or $12^{\circ} \mathrm{C}$ by intramuscular (IM) or intraperitoneal (IP) injection with nodavirus strain H-NV/RI97 isolated from Atlantic halibut Hippoglossus hippoglossus (Expt 1). Control fish kept at $12^{\circ} \mathrm{C}$ were injected with PBS. No mortality occurred in cohabiting groups (not shown) 
mock-infected control group. The mortality observed in the $0.3 \mathrm{~g}$ juveniles was significantly higher than in equally challenged $1 \mathrm{~g}$ juveniles of the same batch $(\mathrm{p}<$ 0.001 , chi ${ }^{2}$-test), although the larger juveniles were kept at a higher temperature.

Virus detection by RT-PCR. NV was detected in the eyes and brain of all dead i.m.- and i.p.-challenged fish

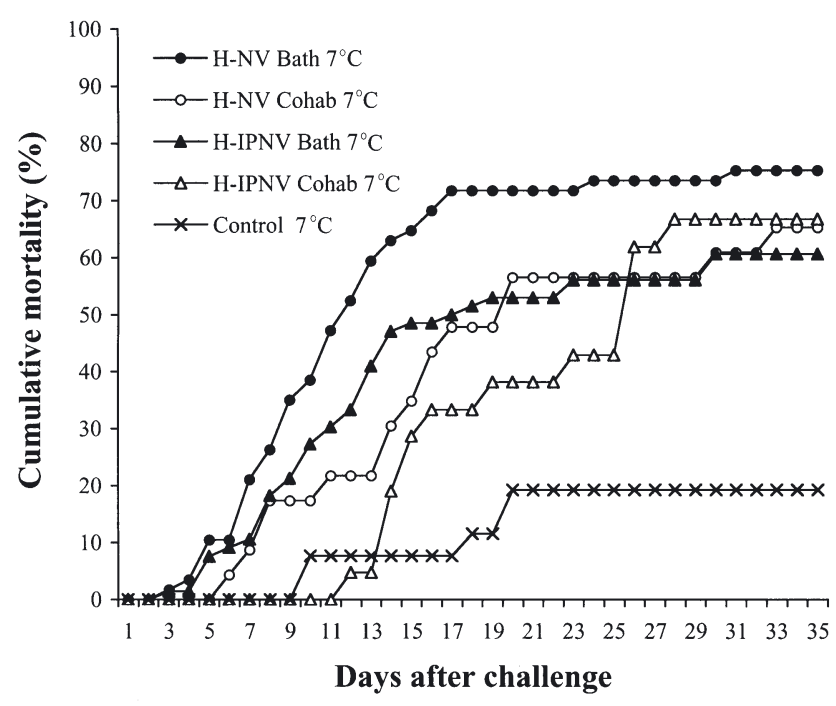

Fig. 2. Anarhichas minor. Cumulative mortality of wolffish juveniles $(0.3 \mathrm{~g})$ bath-challenged at $7^{\circ} \mathrm{C}$ with nodavirus strain H-NV/RI97 or IPN virus strain H-IPNV/GW98 isolated from Atlantic halibut, and infected by cohabitation in the same raceway (Expt 2a,c). Control fish were mock-infected in water containing cell culture medium

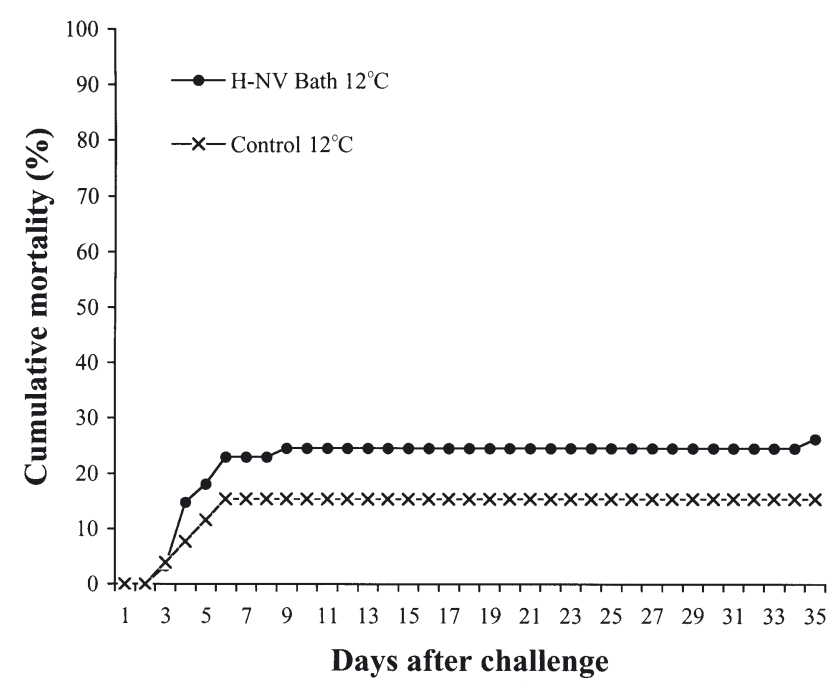

Fig. 3. Anarhichas minor. Cumulative mortality of wolffish juveniles $(1.0 \mathrm{~g})$ bath-challenged at $12^{\circ} \mathrm{C}$ with nodavirus strain H-NV/RI97 isolated from Atlantic halibut (Expt 2b). Control fish were mock-infected in water containing cell culture medium tested in Expt 1. Presence of NV in fish from the cohabitant groups was initially not demonstrated using the RT-PCR method described by Nishizawa et al. (1994). Later, NV-positive cohabitants were detected $10 \mathrm{wk}$ post-challenge by the RT-PCR method described by Grotmol et al. (2000), which was more sensitive to a halibut strain of NV. In Expt 2a and b, NV was detected in dead individuals from both bath-challenged and cohabiting fish of the smallest size kept at $7^{\circ} \mathrm{C}$ and in the larger juveniles kept at $12^{\circ} \mathrm{C}$. The tested fish were collected during the period of acute mortality, 4 to $11 \mathrm{~d}$ post-challenge for the bath-challenged group and 7 to $16 \mathrm{~d}$ for the cohabitants. NV was not detected among survivors from any of the groups sampled at $35 \mathrm{~d}$ postchallenge, or among control fish.

Sequence analysis. The RT-PCR product obtained from the H-NV/RI97 capsid gene using the F2-R3 primers showed that the T4 base sequences of NV reisolated from dead wolffish (Expt 1) and the HNV/RI97 strain used for challenge (Expts 1 and 2) were identical (Fig. 4).

\section{Challenge with IPN virus}

Clinical signs and mortality. No clinical signs or mortality were registered in spotted wolffish of $10 \mathrm{~g}$ after bath-challenge with the Atlantic salmon or halibut IPNV isolates (Expt 1). Appetite, pigmentation and behaviour were normal. Like the VNN-diseased juveniles, clinical signs or abnormal behaviour were difficult to observe in the smallest IPNV-challenged juveniles of $0.3 \mathrm{~g}$, even though mortality was high (Expt 2c). Cumulative mortality reached $61 \%$ among the bath-challenged fish during the experimental period and $67 \%$ in the cohabitant group (Fig. 2). The mortality of both IPNV-infected groups was significantly higher than the background mortality of $19 \%$ among the uninfected juveniles $\left(\mathrm{p}<0.005\right.$, chi $^{2}$-test). The mock-infected control group was the same as that described for the NV challenge (Expt 2a).

No obvious clinical signs were observed among the IPNV-challenged $0.7 \mathrm{~g}$ juveniles either (Expt 3). Mortality after bath-challenge with $\mathrm{H}$-IPNV at $12^{\circ} \mathrm{C}$ started about 3 wk post-challenge and showed a non-acute development (Fig. 5). Cumulative mortality reached $28 \%$ and was significantly higher than the background mortality of $6 \%$ in the mock-infected juveniles $(\mathrm{p}<$ 0.05, chi ${ }^{2}$-test).

Virus detection. Although no mortality was recorded in Expt 1, a sub-clinical viral infection was established. The IPNV was detected in the $10 \mathrm{~g}$ wolffish sampled 3 wk after challenge with H-IPNV or S-IPNV strains (2 of 5 individuals), but not at $5 \mathrm{wk}$ post challenge ( 0 of 6 individuals). In Expt 2c, IPNV was re-isolated from 
1 ACACCTGAAG ATACATTCGC TCCAATCCTA ACCCTGGGAC CACTCTACAA CGACTCCCTT 61 GCACCCAACG ATTTCAAATC AATACTTCTT GGCTCTACCC AGCTTGACAT CGCCCCTGAC 121 GGAGCCGTCT ATTCATTAGA TCGGCCGCTG TCCATTGACT ACAGTCTGGG CACTGGTGAT 181 GTCGACCGTG CCGTTTACTG GCATGTGAAG AAAGTTGCTG GTAATGCGGG AACACCTGCG 241 GGGTGGTTCC ACTGGGGGCT ATGGGATAAT TTCAACAAAA CATTCACACA GGGCGCTGCC 301 TACTATTCTG ATGCGCAGCC TCGACAGATC TTGCTGCCAG TGGGCACGCT CTTCACCCG

Fig. 4. Anarhichas minor. Nucleotide sequence of T4 region of capsid gene from nodavirus strain H-NV/RI97 isolated from Atlantic halibut (Accession No. AJ536693)

dead fish from both bath-challenged and cohabitant group in the period of acute mortality. The virus was also detected in surviving fish collected at the end of the experiment at Week 5 in a pool of 5 fish. In Expt 3, high IPNV titres (from $10^{5}$ to $10^{8} \mathrm{TCID}_{50} \mathrm{~g}^{-1}$ tissue) were detected in dead fish about 4 wk after H-IPNV challenge. Persistence of an IPNV infection 16 wk after challenge was observed in 5 of 12 surviving fish, and titres of $10^{3.5}$ TCID $_{50} \mathrm{~g}^{-1}$ tissue were detected.

\section{DISCUSSION}

Viruses with a broad host-range may pose a risk for new species in an area used for fish farming; however, strains virulent in one species may have low pathogenicity in another. Strain H-NV/RI97 was almost identical (>99\%) to the published T4 sequence of Atlantic halibut strain AH95NorA (Grotmol et al. 2000), but also to $2 \mathrm{NV}$ strains isolated from Dover sole Pleuronectes platessa and Atlantic cod Gadus morhua in the UK (Starkey et al. 2001). There is a lack of species-specificity of piscine NV, and local NV strains may be a risk to several susceptible species in an area (Curtis et al. 2001, Barker et al. 2002). There has been no screening

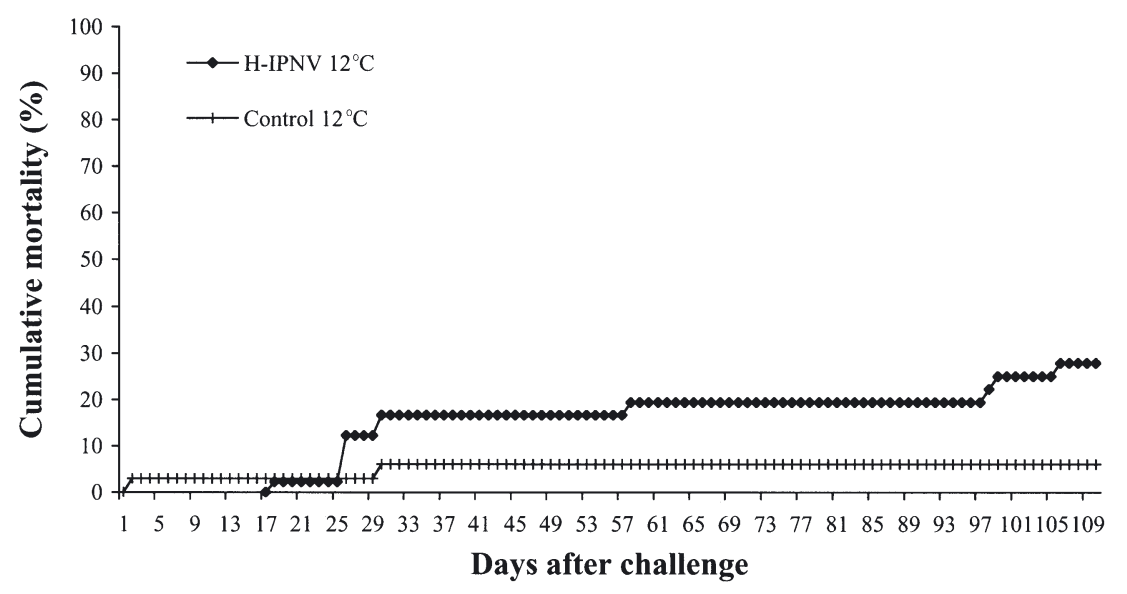

Fig. 5. Anarhichas minor. Cumulative mortality of wolffish juveniles $(0.7 \mathrm{~g})$ challenged by bath at $12^{\circ} \mathrm{C}$ with IPN virus strain H-IPNV/GW98 isolated from Atlantic halibut (Expt 3). Control fish were mock-infected in water containing cell culture medium of wild wolffish for NV or IPNV in Norway yet, but in Canada an NV strain isolated from a covertly infected wild winter flounder was more similar to strains from local cod than those reported from other pleuronectids elsewhere (Barker et al. 2002).

Temperature restriction seems to be more relevant than species-specificity in predicting NV strains of risk to coldwater species. Phylogenetic analysis, based on the nucleotide sequences of T4, has indicated that the Atlantic halibut NV is closely related to the NV isolated from the barfin flounder Verasper moseri and Pacific cod Gadus macrocephalus (Nishizawa et al. 1997, Grotmol et al. 2000). Nodaviruses isolated from these cold-water species have also been shown to be the most psychrophilic strains (Iwamoto et al. 2000). We have previously shown that the H-NV/RI97 is a psychrophilic strain that has an optimal growth at about $18^{\circ} \mathrm{C}$ in the SSN-1 cell line (A.I.S. et al. unpubl. data). NV strains adapted to replication at low temperatures, like H-NV/RI97, will probably represent the highest risk for spotted wolffish, which are usually grown at 4 to $10^{\circ} \mathrm{C}$.

Even though no strains of NV and IPNV isolated from wolffish are yet available, experimental infection with strains isolated from halibut demonstrated that spotted wolffish is susceptible to both viruses and, in general, water-borne infection resulted in mortality among wolffish $<1 \mathrm{~g}$. The smallest juveniles $(0.3 \mathrm{~g}$ ) showed high mortality after bathchallenge with NV and IPNV (75 and $61 \%$ respectively). A water-borne infection, with virus shed from the challenged group, is a more natural mode of infection, and it resulted in high mortality also (65 and $67 \%$ respectively). Cannibalism, whereby fish ate the eyes and abdomen of dead individuals, was observed within the groups and could be another source of viral transmission. However, this was not possible between cohabitants and bath-infected individuals due to the mesh barrier.

Nervous symptoms typical for VNN such as spiral swimming (Munday \& Nakai 1997) were not obvious. However, straightening of their typical curled-up tail was observed. Similarly, clinical signs of IPN in fry such as erratic swimming behaviour (Wolf 1988) were not observed among challenged wolffish. One reason for such differences could be that small wolffish in culture normally rest on the bottom of a raceway, with infrequent bursts of active swimming. 
Large egg size, long incubation time and advanced developmental stage at hatching mean that newly hatched wolffish are more similar to juveniles than larvae, and start feeding within a few days after hatching (Falk-Petersen \& Hansen 2001). Experiments have also shown that development of a functional immune defence starts early in spotted wolffish (Grøntvedt \& Espelid 2003). This may partly explain the rapidly reduced mortality rate due to IPNV and NV infection in 0.7 to $1.0 \mathrm{~g}$ wolffish so soon after first-feeding compared to that in $0.3 \mathrm{~g}$ juveniles. The connection between susceptibility to a viral infection and fish size has also been demonstrated in several other species, including NV infection in striped jack (Arimoto et al. 1993) and IPNV infection in trout, turbot and Atlantic halibut (Dorson \& Torchy 1981, Novoa et al. 1993, Biering et al. 1994). The smallest wolffish juveniles grew very fast at $12^{\circ} \mathrm{C}$ compared to those at $7^{\circ} \mathrm{C}$. Thus, rearing at high temperatures may possibly shorten the period after hatching during which there is the highest risk of disease from water-borne viruses. Conversely, $\mathrm{NV}$-injected wolffish died faster at 12 than at $7^{\circ} \mathrm{C}$, and should the larvae already be infected at hatching high temperature might increase mortality.

Bath-challenge of Atlantic salmon post-smolts with the S-IPNV strain has repeatedly resulted in high mortality in an established experimental model of IPN (A.I.S. et al. unpubl. data). This was not observed in larger juveniles of wolffish $(10 \mathrm{~g})$ challenged with the S-IPNV or the H-IPNV strain using similar bathinfection procedures, although covert IPNV infections were established.

In contrast, injection with NV was $100 \%$ lethal to both the i.m.- and i.p.-injected wolffish $(10 \mathrm{~g})$, but VNN developed more acutely after i.m. than i.p. injection at $7^{\circ} \mathrm{C}$. None of the wolffish cohabitants died. Although the fish species and size differed, Péducasse et al. (1999) also reported $100 \%$ mortality after i.m. injection of NV in $3 \mathrm{~g}$ sea bass Dicentrarchus labrax, while i.p. injection only reached $10 \%$ mortality. They also found i.m. injection of NV the most effective mode of infection compared to bath-challenge $(32 \%)$ and cohabitation $(43 \%)$. It is possible that the i.m. route more quickly infects the central nervous system than i.p.

Symptoms of disease were evident among the NVinjected wolffish, and the first sign was darkening of the skin pigmentation, as reported for sea bass (Péducasse et al. 1999). Inflation of the swim bladder is a common clinical sign of VNN in several species (Munday \& Nakai 1997), but this was not observed since wolffish lack a swim bladder (Barsukov 1959). No corkscrew or looping swim pattern was seen; this could be due to the low water level in the raceways and the resting position on the tank bottom common for this species.
A covert NV infection was detected in the largest cohabiting wolffish juveniles after water-borne virus transmission, and the infection still persisted in some of the fish after $10 \mathrm{wk}$. In a second part of Expt 3 published separately (Johansen et al. 2003), the wolffish juveniles were persistently infected for at least $16 \mathrm{wk}$ post bath-challenge with NV. There was no indication of a persistent infection among the largest juveniles after bath-challenge of the 2 IPNV strains. It is possible that a covert IPNV infection was not sufficient to establish a carrier state, or the virus amount could have been below detection levels. Nevertheless, a subacute, persistent IPNV infection with relatively low mortality did develop in the bath-challenged $0.7 \mathrm{~g}$ wolffish, and IPNV was still detectable 4 mo after challenge. The present results indicate that these 2 widespread viruses may, under certain circumstances, establish a carrier state in juveniles of wolffish.Two important aspects of persistent viral infections, the possibility of recurrence of disease and vertical transmission to progeny, are still unknown in this species.

The present study demonstrates susceptibility to viral infections in spotted wolffish. These experimental infections were performed by bath or injection, but high mortality among the smallest juveniles after cohabitation also indicates the possibility of natural infections. The different challenge experiments provide information about some conditions that may lead to VNN or IPN in cultured spotted wolffish. This species seems, relatively quickly, to reach a size $(>1 \mathrm{~g})$ at which water-borne infections normally will not result in disease. Development of a carrier state is still possible, which again may represent a risk of infection to other wolffish larvae in the area. The demonstrated susceptibility to virus strains, which may be present in other marine species in the environment, should call for precaution. Co-cultivation with other species susceptible to NV or IPNV should be avoided, especially where small wolffish juveniles are concerned.

Acknowledgements. We are grateful to Morten Marienborg and Hans K. Strand for their skilled technical assistance in rearing the juveniles at the Fish Health Laboratory, Kaarvika. The Research Council of Norway has financially supported this study by grants 123752/122 and 124043/120.

\section{LITERATURE CITED}

Altschul SF, Madden TL, Schaffer AA, Zhang J, Zhang Z, Miller W, Lipman DJ (1997) Gapped BLAST and PSIBLAST: a new generation of protein database search programs. Nucleic Acids Res 25(17):3389-3402

Arimoto M, Mori K, Nakai T, Muroga K, Furusawa I (1993) Pathogenicity of the causative agent of viral nervous necrosis disease in striped jack, Pseudocaranx dentex (Bloch \& Schneider). J Fish Dis 16:461-469 
Barker DE, MacKinnon AM, Boston L, Burt MDB and 6 others (2002) First report of piscine nodavirus infecting wild winter flounder Pleuronectes americanus in Passamaquoddy Bay, New Brunswick, Canada. Dis Aquat Org 49:99-105

Barsukov VV (1959) The wolffishes (Anarhichadidae). Fauna SSR Moscow N. S.73. Available from National Technical Information Service, Springfield, VA 22151 (translated by Smithsonian Institute 1972)

Biering E, Nilsen F, Rødseth OM, Glette J (1994) Susceptibility of Atlantic halibut Hippoglossus hippoglossus to infectious pancreatic necrosis virus. Dis Aquat Org 20:183-190

Bristow G, Hjartarson SV (1996) Some blood parasites of the spotted wolfish, Anarhichas minor (Anarhichadidae), taken as broodstock in Icelandic waters. Bull Eur Assoc Fish Pathol 16:119-121

Brown J, Helm H, Moir J (1995) New candidate species for aquaculture. In: Boghen AG (ed) Coldwater aquaculture in Atlantic Canada, 2nd edn. Tribune Press, Sackville, p 341-362

Curtis PA, Drawbridge M, Iwamoto T, Nakai T, Hedrick RP, Gendron AP (2001) Nodavirus infection of juvenile white seabass, Atractoscion nobilis, cultured in southern California: first record of viral nervous necrosis (VNN) in North America. J Fish Dis 24:263-271

Dorson M, Torchy C (1981) The influence of fish age and water temperature on mortalities of rainbow trout, Salmo gairdneri Richardson, caused by a European strain of infectious pancreatic necrosis virus. J Fish Dis 4:213-221

Falk-Petersen IB, Hansen TK (2001) Organ differentiation in newly hatched common wolfish. J Fish Biol 59:1465-1482

Falk-Petersen IB, Hansen TK, Fieler R, Sunde IM (1999) Cultivation of the spotted wolffish Anarhichas minor (Olafsen) - a new candidate for cold-water fish farming. Aquac Res 30:711-718

Frerichs GN, Rodger HD (1996) Cell culture isolation of piscine neuropathy nodavirus from juvenile sea bass, Dicentrarchus labrax. J Gen Virol 77:2067-2071

Grøntvedt RN, Espelid E (2003) Immunoglobulin producing cells in the spotted wolffish (Anarhichas minor Olafsen): localization in adults and during juvenile development. Dev Comp Immunol 27:569-578

Grotmol S, Totland GK, Kvellestad A, Fjell K, Olsen AB (1995) Mass mortality of larval and juvenile hatchery-reared halibut (Hippoglossus hippoglossus L.) associated with the presence of virus-like particles in vacuolated lesions in the central nervous system and retina. Bull Eur Assoc Fish Pathol 15(5):176-180

Grotmol S, Nerland AH, Biering E, Totland GK, Nishizawa T (2000) Characterisation of the capsid protein gene from a nodavirus strain affecting the Atlantic halibut Hippoglossus hippoglossus and design of an optimal reverse-transcriptase polymerase chain reaction (RT-PCR) detection assay. Dis Aquat Org 39:79-88

Hellberg H, Moksness E, Høie S (1996) Infection with atypical Aeromonas salmonicida in farmed common wolffish, Anarhichas lupus L. J Fish Dis 19:329-332

Iwamoto T, Nakai T, Mori K, Arimoto M, Furusawa I (2000) Cloning of the fish cell line SSN-1 for piscine nodaviruses. Dis Aquat Org 43:81-89

Johansen LH, Sommer AI (2001) Infectious pancreatic necrosis virus infection in Atlantic salmon Salmo salar postsmolts affects the outcome of secondary infections with infectious salmon anaemia virus or Vibrio salmonicida. Dis Aquat Org 47(2):109-117

Johansen R, Ranheim T, Hansen MK, Taksdal T, Totland GK (2002) Pathological changes in juvenile Atlantic halibut Hippoglossus hippoglossus persistently infected with nodavirus. Dis Aquat Org 50:161-169

Johansen R, Amundsen M, Dannevig BH, Sommer AI (2003) Acute and persistent experimental nodavirus infection in spotted wolffish Anarhichas minor. Dis Aquat Org 57:35-41

Johnson SC, Sperker SA, Leggiadro CT, Groman DB, Griffiths SG, Ritchie RJ, Cook MD, Cusack RR (2002) Identification and characterization of a piscine neuropathy and nodavirus from juvenile Atlantic cod (Gadus morhua). J Aquat Anim Health 14:124-133

Krogsrud J, Håstein T, Rønningen K (1989) Infectious pancreatic necrosis virus in Norwegian fish farms. In: Ahne W, Kurstak E (eds) Viruses of lower vertebrates. SpringerVerlag, Berlin, p 284-291

Lannan CN, Winthon JR, Fryer JL (1984) Fish cell lines: establishment and characterization of nine cell lines from salmonids. In Vitro 220:671-676

Melby HP, Krogsrud J, Håstein T, Stenwig, H (1991) All commercial Atlantic salmon seawater farms in Norway harbour carriers of infectious pancreatic necrosis virus (IPNV). In: Fryer JL (ed) Proc 2nd Int Symp Viruses of Lower Vertebrates. Oregon State University, Corvallis, p 211-217

Munday BL, Nakai T (1997) Special topic review: nodaviruses as pathogens in larval and juvenile marine finfish. World J Microbiol Biotechnol 13:375-381

Nishizawa T, Mori K, Nakai T, Furusawa I, Muroga K (1994) Polymerase chain reaction (PCR) amplification of RNA of striped jack nervous necrosis virus (SJNNV). Dis Aquat Org 18:103-107

Nishizawa T, Furuhashi M, Nagai T, Nakai T, Muroga K (1997) Genomic classification of fish nodaviruses by molecular phylogenetic analysis of the coat protein gene. Appl Environ Microbiol 63(4):1633-1636

Novoa B, Figueras A, Puentes CF, Ledo A, Toranzo AE (1993) Characterization of a birnavirus isolated from diseased turbot cultured in Spain. Dis Aquat Org 15:163-169

Pearson WR (1990) Rapid and sensitive sequence comparison with FASTP and FASTA. Methods Enzymol 183:63-98

Péducasse S, Castric J, Thiéry R, Jeffroy J, Le Ven A, Baudin Laurencin F (1999) Comparative study of viral encephalopathy and retinopathy in juvenile sea bass Dicentrarchus labrax infected in different ways. Dis Aquat Org 36:11-20

Reed JL, Muench H (1938) A simple method for estimating fifty percent end points. Am J Hyg 27:493-497

Smail DA, Bruno DW, Dear G, McFarlane LA, Ross K (1992) Infectious pancreatic necrosis (IPN) virus Sp serotype in farmed Atlantic salmon, Salmo salar L., post-smolt associated with mortality and clinical disease. J Fish Dis 15: $77-83$

Starkey WG, Ireland $\mathrm{JH}$, Muir KF, Jenkins ME, Roy WJ, Richards RH, Ferguson HW (2001) Nodavirus infection in Atlantic cod and Dover sole in the UK. Vet Rec 149: 179-181

Taksdal T, Stangeland K, Dannevig, BH (1997) Induction of infectious pancreatic necrosis (IPN) in Atlantic salmon Salmo salar and brook trout Salvelinus fontinalis by bath challenge of fry with infectious pancreatic necrosis virus (IPNV) serotype Sp. Dis Aquat Org 28:39-44

Wardlaw AC (1995) How to deal with proportion data. In: Wardlaw AC (ed) Practical statistics for experimental biologists. John Wiley \& Sons, Chichester, p 92-117

Wolf K (1988) Infectious pancreatic necrosis. In: Wolf K (ed) Fish viruses and fish viral diseases. Cornell University Press, Ithaca, NY, p 115-157

Wood BP, Bruno DW, Ross K (1996) Infectious pancreaticnecrosis virus (IPNV) mortalities among farmed Atlantic halibut, Hippoglossus hippoglossus L., in Scotland. Bull Eur Assoc Fish Pathol 16(6):214-216 